\title{
Research on Lexical Approach in College English Reading Teaching in Ethnic Minority Areas
}

\author{
Mingbo $\mathrm{Yu}$ \\ Department of Foreign Languages Education, Chifeng University, Chifeng , Inner Mongolia \\ 024000 China
}

Keywords: Lexical approach; Ethnic minority areas; English reading teaching

\begin{abstract}
With the rise and popularization of Lexical Approach Teaching, in order to promote the quality of college English reading teaching in the minority areas this article expounds the application of Chunk Teaching Method in the minority areas using experiment process to demonstrate the feasibility and effectiveness of Chunk teaching .
\end{abstract}

\section{Introduction}

Lexical approach is the focus of English teaching research in recent years. The lexical chunk is a kind of linguistic unit larger than the word and smaller than the sentence (Ma Guanghui, 2011). Lexical chunk has the advantage of integrating grammar, semantics, pragmatics and context, so lexical approach becomes a good teaching method. A large number of scholars have investigated the mastery and use the ability of English learners. The research shows that there are a large number of prefabricated language structures in English (Lewis, 1997; Ellis, 1984), and the stronger the lexical mastery, the more fluently English learners can use the language.

Ethnic minority areas are remote in location, with relatively backward teaching resources and equipment, so they are weak in English proficiency. Teachers and students do not often use some advanced teaching methods. It has been proved by the research (Zhang Yuying, 2008) that English learners' lexical mastery ability is significantly related to their English proficiency. However, even those with good English proficiency need to be trained in order to better grasp the recognition ability of words and to achieve the purpose of improving English proficiency.

\section{Research Design}

Research Purposes. English reading is divided into top-down and bottom-up understanding processes, and the lexical approach can well promote students' bottom-up understanding process. This article is intended to explore whether the use of lexical approach teaching and training can improve students' English reading ability and level in ethnic minority areas.

Research Objects. In this study, students from two classes at Chifeng University were selected as research subjects. Chifeng College is located in Inner Mongolia ethnic minority areas, the majority of student sources come from the Inner Mongolia region. These two classes are new undergraduate classes. Our research set one class for the experimental class, the other class for the control class. The student number of experimental class is 37 , and the student number of control class is 58.

Research Materials. In this experiment, in order to ensure the reliability and validity of the experiment, we selected the test paper of CET4 as the pre-test and post-test paper for reading ability test of students. English lexical chunk test intercepted Diao Linlin's (2004) English undergraduates' vocabulary ability test papers. In the teaching experiment process, experimental and control class use the same textbook. They are New World University English 1, 2 which are published by the Foreign Language Teaching and Research Press and some of the CET4 and CET6 test papers are distributed to students as supplementary materials.

Research Process. In this study, two parallel classes were choosen at Chifeng University to conduct this teaching research. In order to ensure the accuracy of the experiment, first of all, 
students of two classes were surveyed in English reading ability and word mastery level. Two classes conducted a pre-test at the same time. The papers are the same.

\section{Group Statistics}

\begin{tabular}{|c|c|l|l|}
\hline Class & $\begin{array}{l}\text { Student } \\
\text { number }\end{array}$ & $\begin{array}{l}\text { Average grade of } \\
\text { CET4 reading }\end{array}$ & $\begin{array}{l}\text { Average grade of } \\
\text { lexical chunk }\end{array}$ \\
\hline $\begin{array}{c}\text { Control class } \\
\text { Experimental } \\
\text { class }\end{array}$ & 57 & 67 & 9.63 \\
\hline
\end{tabular}

Table 1.

According to Table 1, the pre-test scores of experimental class and control class in English reading are 67 and 70. The pre-test scores of experimental class and control class are 9.63 and 10.34 . These data can show that these two classes are at the same level in English reading and lexical mastery .

\begin{tabular}{|l|c|l|}
\hline \multicolumn{2}{|c|}{ t-test for Equality of Means } \\
\hline $\begin{array}{l}\text { Equal } \\
\text { variances } \\
\text { assumed }\end{array}$ & English reading scores Sig. (2-tailed) & $\begin{array}{l}\text { Lexical chunk scores Sig. } \\
\text { (2-tailed) }\end{array}$ \\
\cline { 2 - 3 } & .825 & .171 \\
\hline
\end{tabular}

\section{Table 2.}

In Table 2, a T-test was carried out. The test's original hypothesis was that the two classes had the same variance. From the test results we can see that Sig. (2-tailed) is 0.825 and 0.171 , that is to say the significance level of $\mathrm{T}$ - test is 0.825 and 0.171 . These two values are far greater than 0.05 , so there are no significant differences between the control class and experimental class. The assumption of equal means for both classes holds. Both classes have the same level of English reading. Similarly, the two parallel classes of students in this experiment also do not have significant differences in terms of lexical chunk mastery, and the use skills of lexical chunk is basically the same. As the two classes are roughly the same in English reading ability and the mastery of lexical chunk, this teaching experiment has the basis to compare.

The duration of this teaching experiment is 22 weeks. The teachers in both classes are the same. The class time is 3 lessons per week. The experimental test materials, teaching materials and supplementary materials are the same. Neither class has received systematic lexical training.

The two classes participating in the teaching research experiment adopt different reading teaching methods: the experimental class adopts the lexical approach for teaching, while the control class adopts the traditional teaching method for teaching. The specific teaching and research process is as follows: the control class adopts the traditional teaching mode for teaching, and the teacher pays attention to the grammar and single word explanation in the teaching process. Throughout the teaching process, teachers do not use lexical chunk teaching method, do not instill a sense of lexical chunk. In the experimental class, students are given a sense of lexical chunk in the beginning of the experiment. First of all, let the students understand what is lexical chunk, and gradually allow students to independently identify the lexical chunk, train students to learn and use lexical chunk, and finally build a complete system of lexical chunk awareness. When previewing the text, students should be conscious to sort out the content by the lexical chunk as a unit but not by the word. In the process of teaching, teachers should also focus on the lexical explanation. Upon completion of the lecture, students will discuss what they have learned in groups, compare the contents of the pre-lesson lexicon and the lecture of the lexicon by the teacher, so that mark the key content with a striking marker. When doing the after-class review, students also focus on the review of the phrase. There are lexical exercises in New World University English, such as brainwash / talk / force etc someone into doing something. When students do such exercises, teachers can focus on explaining 
and replacing exercises, enhance students' awareness of lexical chunk learning. In the face of similar expressions of lexical chunk, teachers need to give different chunks, in order to let students to increase the amount of lexical chunks. For example, when explaining "have the ability to do something", the teacher can give "enable somebody to do something, able to do something, be capable of doing something" to allow students to discuss and practice, and gradually allow students to learn to summarize the lexical chunks with the same meaning.

After 22 weeks of teaching and training, students have set up a learning mode which is based on lexical chunks. The lexical approach runs through the pre-class preview, class discussion, review after class, and constantly enhance the students' vocabulary awareness and the ability to use the lexical chunk in English learning.

\section{Research Experimental Results and Data Analysis}

In this experiment, experimental class and control class participate in two tests of pre-test and post-test for a total of four test papers. In front of this article, we have analyzed the student's pre-test results and data analysis shows that the two classes are at about the same level in English reading ability and lexical chunk mastery, so the experiment can be conducted. After being taught by different teaching methods for 22 weeks, the experimental class and control class are tested. According to the social statistics software SPSS, the statistical results are as follows:

Group Statistics

\begin{tabular}{|l|c|l|l|}
\hline Class & $\begin{array}{l}\text { Number of } \\
\text { people }\end{array}$ & $\begin{array}{l}\text { Average score of CET4 } \\
\text { reading }\end{array}$ & $\begin{array}{l}\text { Average score } \\
\text { of lexical chunk }\end{array}$ \\
\hline Control class & 57 & 102 & 12.61 \\
Experimental class & 38 & 118 & 15.28 \\
\hline
\end{tabular}

Table 3.

From Table 3, we can see that after 22 weeks of study, the average score of CET4 reading of both classes has been improved, and the experimental class is better than the control class. The average grade of lexical chunk of the experimental class was 15.28, the control class was 12.6. The experimental class is higher than that of the control class. Then a separate sample T-test was carried out, the data are as follows:

\begin{tabular}{|c|c|c|c|c|}
\hline & \multicolumn{4}{|c|}{ t-test for Equality of Means } \\
\hline \multirow{2}{*}{$\begin{array}{l}\text { Equal } \\
\text { variances } \\
\text { assumed }\end{array}$} & $\begin{array}{l}\text { English } \\
\text { (2-tailed) }\end{array}$ & reading & score Sig. & $\begin{array}{l}\text { Lexical chunk score Sig. } \\
\text { (2-tailed) }\end{array}$ \\
\hline & .002 & & & .000 \\
\hline
\end{tabular}

Table 4.

In Table 4, T-test was conducted. According to the test results, Sig. (2-tailed) values of English reading score and lexical chunk score are 0.002 and 0.000 , and both values are less than 0.05 . That is to say, from a statistical point of view, it can be proved that there are significant differences between the experimental class and the control class in this study after 22 weeks of teaching and research experiments. This also means that the experimental class has better reading performance than the control class. Especially in the test of lexical mastery degree, there are significant differences between experimental class and control class. The ability of experimental class to grasp and use words has been far superior to that of control class. The lexical approach has shown its positive role in lexical teaching in English reading teaching. The English reading and lexical results of the experimental class have significant advantages over the control class.

Based on the experimental data collected above, we can see that there is no significant difference between the reading and the lexical performance of the two classes before the teaching of the lexical teaching. Based on the experimental data collected above, we can see that there is no significant 
difference between the reading and the lexical performance of the two classes before the teaching of the lexical teaching. After 22 weeks of teaching experiment, due to the implementation of different teaching methods in experimental class and control class, lexical teaching method shows its teaching effect, the difference between experimental class and control class shows significant differences, which also indicates that the lexical approach is suitable for English reading teaching, can promote the quality of English reading teaching and improve students' English reading.

\section{Conclusion}

Ethnic minority areas are located in remote areas, economic, education and culture are more backward, so the students are relatively weak in English learning and urgently need to improve their English proficiency. The lexical approach can promote students' understanding of bottom-up process in English learning, thereby enhancing students' ability to understand English and eventually achieve the purpose of improving students' English learning. The teaching experiment lasted for 22 weeks. The resaults have shown that the implementation of lexical approach in English teaching can indeed improve students' English reading ability. Teachers in ethnic minority areas can use the lexical approach throughout the teaching, cultivate students' cognitive ability of lexical chunk, increase the amount of students' lexical chunk, enhance students' frequency of using it, help students to establish a complete lexical learning and usage system, and internalize students' lexical awareness. Lexical approach can achieve the ultimate goal of improving students' English learning ability and level.

\section{References}

[1] Ellis, r. Formulaic Speech in Early Classroom Second Language Development.1984.

[2] Lewis. The Lexical Approach: Putting Theory in Practice [J]. Hove: Language Teaching Publication, 1997.

[3] Ma Guanghui. Study of lexical blocks in English majors [J]. Foreign language teaching and research, 2009,01:54-60+81.

[4] Zhang Yuying. The study of the relationship between prefabricated word block recognition and two-language proficiency in the second language learners $[\mathrm{J}]$. Foreign language world, 2008,03:62-66.

[5] A lexical phrase grammar for ESL. Nattinger J. Tesol Quarterly . 1980

[6] Formulaic language in learners and native speakers. Wray,A. Language Teaching . 1999

[7] The Grammatical and Lexical Patterning of MAKE in Native and Non-native Student Writing. Altenberg,B,\& Granger,S. Applied Linguistics . 2001

[8] Lexical Phrases and Language Teaching. Nattinger, J. R,\& DeCarrico, J. S. . 1992 